\section{Growth and Productivity of 'Consort' Black Currant Grown under Varying Levels of Artificial Shade}

\author{
Eric T. Wolske and Bruce E. Branham \\ Department of Crop Sciences, University of Illinois, Plant Sciences \\ Laboratory, 1201 South Dorner Drive Urbana, IL 61801
}

Kevin J. Wolz

Savanna Institute, 1360 Regent Street \#124, Madison, WI 53715

Additional index words. Ribes nigrum, understory production, forest farming, multi-story cropping

\begin{abstract}
The shade tolerance of black currants (Ribes nigrum cv. Consort) was studied by measuring the growth and productivity of mature plants in the field for three seasons under full sun or artificial shade netting in Urbana, IL. Shade treatments reduced photosynthetically active radiation $(P A R)$ from $37 \%$ to $83 \%$. Yield was not reduced in shade levels up to $65 \%$ but decreased by as much as $66 \%$ under $83 \%$ shade. Shade had minimal effect on stem rejuvenation in the first 2 years, but reduced rejuvenation in the third year from 14 new stems in full sun to eight new stems in $83 \%$ shade. Stem diameter decreased $8 \%$ to $19 \%$ with $83 \%$ shade, whereas no changes were observed in up to $65 \%$ shade. Plant height increased $5 \%$ to $8 \%$ from open sun to $83 \%$ shade. Specific leaf weight decreased and leaf area increased with shade. Powdery mildew severity increased with shade, and disease-resistant cultivars should be considered for understory crops. Our results indicate that growth and productivity of black currants can be maintained in moderate shade but shade levels beyond $65 \%$ will significantly reduce agronomic performance.
\end{abstract}

Multifunctional polycultures have been theorized to provide a significant array of functions and services including enhanced landscape productivity, ecological services, and economic profitability and stability (Lovell et al., 2017; Wolz et al., 2018). The focus of these systems is on shifting our agricultural paradigm from monoculture, single-purpose, annual cropping systems toward polyculture, multifunctional, perennial cropping systems. A major issue in polyculture and mixed cropping systems is plant-toplant competition. Light availability is a major component of plant competition resulting in reduced plant productivity and yield for shaded plants. Two distinct ecological niches exist within these larger, multilayered polyculture systems: the overstory and the understory. In the understory, the greatest competition comes from changes in light quantity and light quality (Malézieux et al., 2009). In natural ecosystems, the understory is inhabited by plants that are shade tolerant and capable of efficient utilization

Received for publication 30 Apr. 2020. Accepted for publication 8 July 2020 .

Published online 23 November 2020.

This research was supported in part by a grant from the Illinois Department of Agriculture's Specialty Crop Grants program.

B.E.B. is the corresponding author. E-mail: bbranham@ illinois.edu.

This is an open access article distributed under the CC BY-NC-ND license (https://creativecommons. org/licenses/by-nc-nd/4.0/). of the reduced light amounts and quality By filling individual ecological niches within the built ecosystem, plant competition can be reduced while facilitating increased productivity.

Shade tolerance and intolerance exist along a spectrum, with plants ranging between high light tolerant and high light intolerant, i.e., sun plants or shade plants. The damage to plants under excessive light irradiance includes plant desiccation and ultraviolet radiation stress (Valladares and Niinemets, 2008; Valladares et al., 2016). Shade-tolerant plants tend to be more plastic in morphological adaptations to optimize light capture and increase photosynthetic efficiencies at low light levels (Bayala et al., 2015; Valladares and Niinemets, 2008). Shade-tolerant species maintain a lower relative growth rate than shade-intolerant species under both shade and open conditions (Gommers et al., 2013).

Previous research has been conducted on the effects of shading on the growth and productivity of several berry crop species. In blackberries, Gallagher et al. (2015) found optimal vegetative performance with $30 \%$ shade but incomplete or delayed floral bud differentiation with shade between $50 \%$ and $80 \%$. When experimenting with an applethat blackberry yield was reduced when grown in polyculture, jostaberry yield was unaffected, and the yield of one cultivar of edible honeysuckle was unaffected whereas (Boardman, 1977; Valladares et al., 2016). berry polyculture, Rivera et al. (2004) found another showed enhanced yield when cultured with apple. In grapes, shade limited meristem growth and shoot biomass (Greer et al., 2010), and altered leaf morphology (Heuvel et al., 2004). In coffee, plant performance was increased due to improved photosynthesis and morphological changes favoring an increased leaf area index (Bote and Struik, 2011). In blueberries, Kim et al. (2011) found that shading decreased the number of shoots per shrub but increased shoot length, while increasing leaf area and decreasing leaf thickness. As the level of shading increased, plant yield decreased, and the authors concluded that shade levels should be no more than $60 \%$ for blueberries to remain economically viable.

Black currants (Ribes nigrum) have an interesting history in the United States (Hummer and Barney, 2002). Ribes spp. and white pines are part of a disease pathosystem caused by the fungus Cronartium ribicola (Geils et al., 2010). White pines are infected only from basidiospores produced by infected Ribes spp. In the United States, the forest and paper products industry successfully lobbied the federal government to eradicate Ribes spp. from the United States. Currants were banned by the U.S. government in the 1920s and existing plantings were eradicated. The federal ban was lifted in 1966 but individual states continued to ban or partially ban currants. For example, Massachusetts continues to ban black currants, but allows the cultivation of other Ribes spp. on a town-by-town basis, whereas Delaware, New Jersey, and North Carolina still ban all Ribes spp. Thus, most U.S. consumers have not tasted black currants nor developed an appreciation for the taste and health properties of currants. In response to the white pine blister rust disease, Canadian breeder A.W. Hunter released three black currant varieties, Consort, Coronet, and Crusader, that carry a resistance gene to the disease (Hunter, 1955).

Black currant is a highly nutritious berry crop with high levels of antioxidants, quick growth to maturity (3 to 5 years), cold tolerance, and early fruiting (Gopalan et al., 2012; Hummer and Dale, 2010). Currants are a berry crop with excellent potential as an understory crop. In the wild, black currants and other Ribes spp. naturally occur in understory environments. They are also known to grow and yield well under shaded agronomic conditions (Djordjevic et al., 2014; Šavikin et al., 2013; Toldam-Andersen and Hansen, 1993); however, empirical research to determine the optimal shade levels for black currant production is limited. Previous studies found reduced lighting affects currant physiology, including impacts on flower initiation, number and length of nodes, and yield (Toldam-Andersen and Hansen, 1993). Shade may also decrease fruit damage due to a reduction of light intensity that causes sunburn and plant stress (Djordjevic et al., 2014). Much of the previous shade research has been conducted to determine the connection between shade and temperature with the goal of reducing plant temperature to 


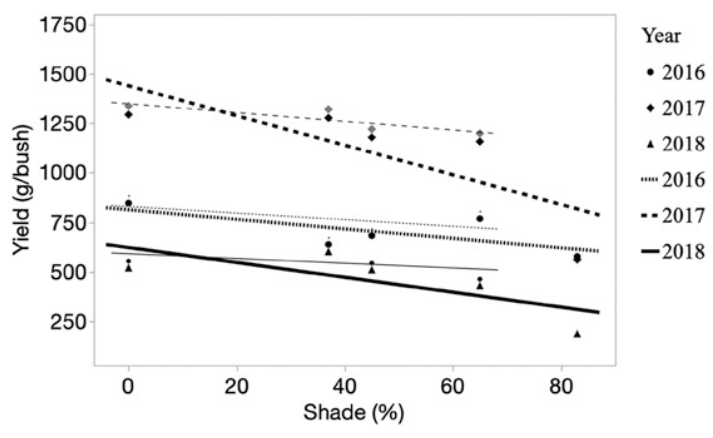

Fig. 1. Artificial shade effects on yield per plant of 'Consort' black currant grown in Urbana, IL. Yield is presented for 2016, 2017, and 2018. Values are given as grams per bush plus or minus standard error. Thicker lines represent fit line with all treatments, whereas thinner lines represent fit line with the $83 \%$ shade treatment removed. Regression equations (where $\mathrm{x}=$ percent shade) were as follows: Yield $(2016)=812.4-2.398 \mathrm{x}, r^{2}=0.24, P=0.03$; Yield $(2017)=1439+7.498 \mathrm{x}, r^{2}=0.046, P=$ 0.001 ; Yield $(2018)=622.2-3.751 \mathrm{x}, r^{2}=0.35, P=0.006$. Regression without $83 \%$ shade was not significant with $P=0.2762, P=0.2657$, and $P=0.4300$, for 2016, 2017, and 2018, respectively.

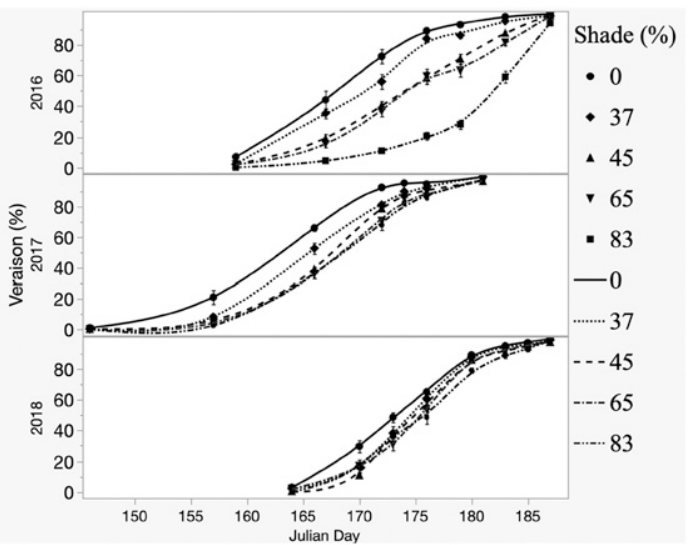

Fig. 2. Artificial shade effects on 'Consort' black currant berry ripening by Julian days grown in Urbana, IL. Berry ripening was recorded as percent veraison per bush and is presented for 2016, 2017, and 2018.

improve fruit quality and plant vigor while maintaining adequate yield. Instead of temperature modulation, our research seeks to determine the limitations to understory crops in polyculture systems.

The use of productive understory crops can help expand potential niches in agricultural systems by filling gaps in the landscape to maximize agronomic light capture. The ecological role of currants as an understory species suggests black currants may be a suitable understory crop in a polyculture system that will result in increased productivity per unit land area. The objective of this research was to explore the effects of shade on black currants in a temperate climate by assessing the impact on yield, morphology, phenology, and disease susceptibility.

\section{Materials and Methods}

Study site and experimental design. This study was conducted in 2016 through 2018 on the Woody Perennial Polyculture site at the University of Illinois Fruit Farm in Urbana, IL (40.079227, -88.216004). Soil types are a Flanagan series (fine, smectitic, mesic Aquic Argiudolls) and a Thorp series (fine-silty, mixed, superactive, mesic Argiaquic Argialbolls). The site has east-west orientation with 'Consort' black currant established in 2012 (4 years old at trial initiation) set at $1.2-\mathrm{m}$ spacing between plants and 4.8-m spacing between rows. Plants were fertilized in Spring 2016 and 2018 with urea at a rate of $112 \mathrm{~kg} \mathrm{~N} / \mathrm{ha}$ and in Spring 2017 with poultry manure at a rate of $112 \mathrm{~kg} \mathrm{~N} / \mathrm{ha}$. Soil tests showed adequate levels of $\mathrm{K}$ and $\mathrm{P}$ and no supplement application of these nutrients was made. Organic certification was being considered in 2017 , hence the poultry manure application, but was abandoned by 2018 . Powdery mildew was the only disease readily observed. Plants were treated with drenches of $2.6 \%(\mathrm{v} / \mathrm{v})$ horticultural oil (Ultra-Pure; BASF Corporation, Research Triangle Park, NC) on 23 May 2016 and 1.9\% (v/v) horticultural oil on 15 and 30 May 2017, 20 June 2017, and 11 May 2018. Horticultural oil provided limited control of powdery mildew and so $\mathrm{KHCO}_{3}$ (Mil-stop; Bioworks, Victor, $\mathrm{NY})$ was tank mixed at $3 \mathrm{~g} \cdot \mathrm{L}^{-1}$ with $1 \%(\mathrm{v} / \mathrm{v})$ horticultural oil and applied on 14 June 2018 to increase mildew control.

Weeds were removed in a $1.2-\mathrm{m}$ band around plants using glyphosate, dicamba, and light tillage in 2016, light tillage only in 2017, and glyphosate in 2018. Dormant plants were pruned to select roughly four 1year stems, four 2-year stems, and four 3-year stems for an average of 10 to 12 stems per plant post-pruning.

Four artificial shade treatments were used in addition to a full-sun control. Shade netting at nominal levels of $20 \%$ white, $30 \%$ black, 50\% black, and 70\% black (Dewitt Company, Sikeston, MO) were each placed over blocks of six currant plants. Average daytime reduction in $P A R$ under each shade treatment was measured with an LI-190 (LICOR Biosciences, Lincoln, NE) at 37\%, $45 \%, 65 \%$, and $83 \%$, respectively. These measured values were used in all analyses. A $90 \%$ black shade netting treatment was initially deployed in 2016 but was replaced in early May of that same year, before full flower bloom, with the $20 \%$ white shade netting. White shade netting was used because we could not find a $20 \%$ black shade netting. Metal conduit was used to create a gothic frame structure $3 \mathrm{~m}$ wide and $1.8 \mathrm{~m}$ high in the center and slanting down to $0.9 \mathrm{~m}$ at the edges. The shade structure extended past the end plants by $0.9 \mathrm{~m}$. The shade netting was installed in early spring before full leaf out on 12 Mar. 2016 and before full flower bloom on 13 and 14 Apr. in 2017 and 2018, respectively. Shade netting was removed after leaf fall in late November in all three years. Experimental design was a randomized complete block with four blocks. Each plot consisted of six plants, with the outer two plants serving as buffers and data collected from the center four plants.

Measurements and analyses. Berry ripeness was tracked from the onset of veraison to full peak ripeness. Veraison is a term used in viticulture to describe the ripening process of berries based on color change, softening, and biochemical change of the berries. Veraison was recorded as the percentage of berries with dark purple coloring and was visually estimated weekly for each plant and averaged by plot. Treatments were harvested by hand when an average of $95 \%$ veraison was reached per treatment. In 2016, all treatments were harvested on 5 July. In 2017, the control and 37\% treatments were harvested on 27 June whereas the $45 \%, 65 \%$, and $83 \%$ treatments were harvested on 1 and 2 July. In 2018, all treatments were harvested on 6 July. Yield data are reported as grams per bush.

Plant height was measured in May after flowering. Leaf area and weight were measured per plant after bloom break in May by randomly selecting five mature leaves from the middle of the stem. Leaf area was measured using a CI-202 Portable Laser Leaf Area Meter (CID Bio-Science, Inc., Camas, WA). Fresh and dry weights were taken before and after drying the leaves for a minimum of $72 \mathrm{~h}$ at $50{ }^{\circ} \mathrm{C}$. Specific leaf weight (SLW) was recorded as mg dry weight per $\mathrm{cm}^{2}$ of leaf area

Stem morphology was measured during plant dormancy from November to March. 


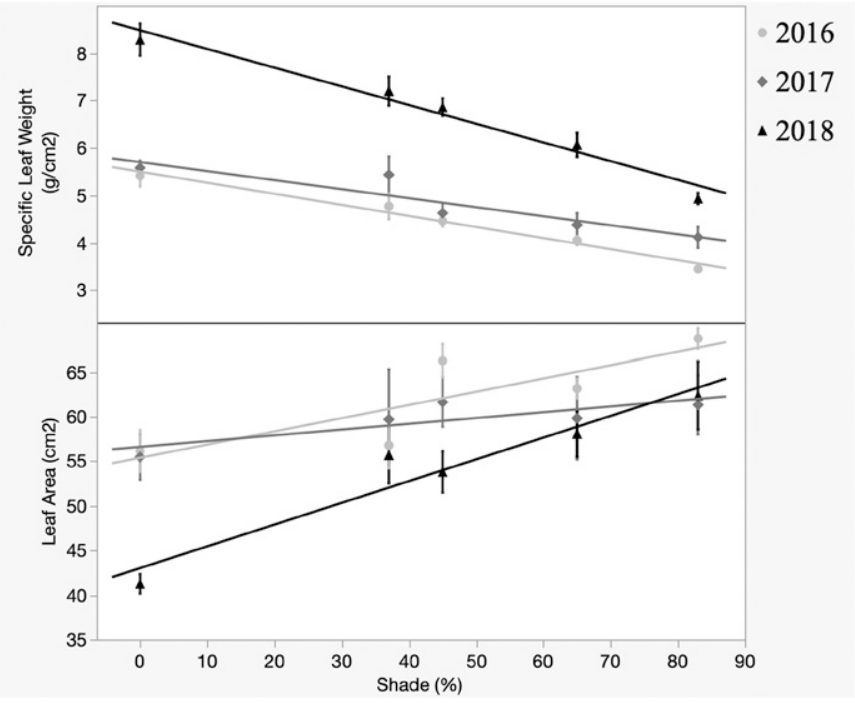

Fig. 3. Artificial shade effects on leaf area $\left(\mathrm{cm}^{2}\right.$, top) and specific leaf weight (SLW; $\mathrm{g} \cdot \mathrm{cm}^{-2}$, bottom) of 'Consort' black currant grown in Urbana, IL. SLW and leaf area are presented for 2016, 2017, and 2018. Error bars represent standard error. Regression equations (where $\mathrm{x}=$ percent shade): $\operatorname{SLW}(2016)=$ $5.503-0.023 \mathrm{x}, r^{2}=0.81, P=0.0001 ; \mathrm{SLW}(2017)=5.704-0.019 \mathrm{x}, r^{2}=0.54, P=0.0002 ; \mathrm{SLW}(2018)=$ $8.481-0.039 \mathrm{x}, r^{2}=0.84, P=0.0001$; Leaf area $(2016)=55.38+0.148 \mathrm{x}, r^{2}=0.48, P=0.0007$; Leaf $\operatorname{area}(2017)=56.60+0.0648 \mathrm{x}, r^{2}=0.06$, not significant; Leaf area $(2018)=43.01+0.244 \mathrm{x}, r^{2}=0.64, P=$ 0.0001 .

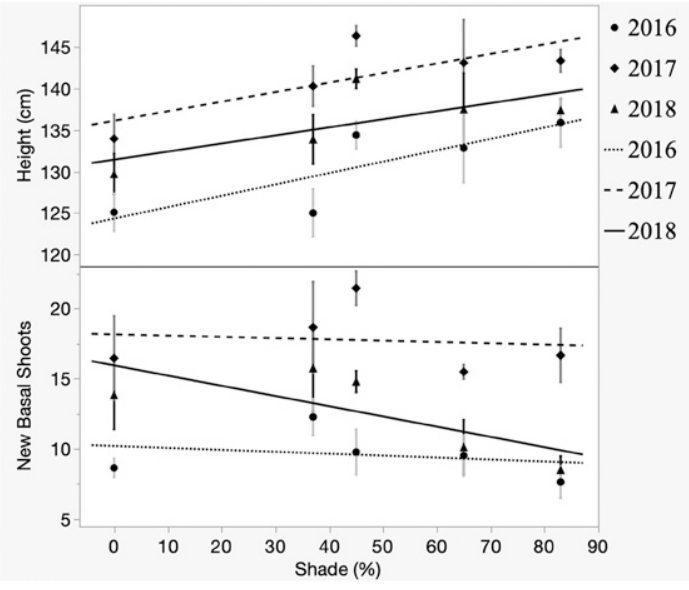

Fig. 4. Artificial shade effect on 'Consort' black currant height (top) and stem rejuvenation (bottom) grown in Urbana, IL. Height and stem rejuvenation are presented for 2016, 2017, and 2018. Values for height are given as mean $\mathrm{cm}$ plus or minus standard error. Values for stem rejuvenation are given as the mean number of new basal stems per bush plus or minus standard error. Regression equations (where $\mathrm{x}=$ percent shade) were as follows: Height $(2016)=124.3+0.1369 \mathrm{x}, r^{2}=0.31, P=0.0103$; Height $(2017)=$ $136.1+0.1148 \mathrm{x}, r^{2}=0.23, P=0.0304$; Height $(2018)=131.4+0.0973 \mathrm{x}, r^{2}=0.20, P=0.0475$; New Shoots $(2016)=10.18+0.0138 \mathrm{x}, r^{2}=0.02, P=0.5466$; New shoots $(2017)=18.16+0.0091 \mathrm{x}, r^{2}=$ $0.003, P=0.8082$; New $\operatorname{shoots}(2018)=15.94+0.0730 \mathrm{x}, r^{2}=0.21, P=0.0445$.

Individual basal stem diameter per plant was measured with calipers and separated into new, first year, and mature stems 2 years and older. The number of new stems was counted to determine stem rejuvenation, and the average stem diameter for both new and old stems was calculated.

Fungicide treatment only limited powdery mildew severity and did not provide complete control. Plant powdery mildew severity was evaluated from May until August in 2017 and 2018. Plant injury was rated on a 10-point ordinal disease scale: $0=$ no powdery mildew; 1 = powdery mildew detected; $2=6$ to
20 leaves damaged, presence of powdery mildew mycelium; $3=20+$ leaves damaged or infected; $4=$ deep leaf browning; $5=$ full tissue necrosis on leaves and powdery mildew on shoot tips; $6=$ necrosis of old shoots and leaves; $7=$ plant dieback and/or infected fruit; $8=+50 \%$ plant tissue necrosis; $9=$ plant death. Powdery mildew damage was most severe the third week of June in 2017 and 2018. Statistical analysis was performed on the date with the most severe ratings each year: 23 June 2017 and 25 June 2018.

Statistical analysis was performed using JMP Pro (14.2.0; SAS Institute, Cary, NC).
The effects of year, shade, block, and year by shade interaction were analyzed using 2-way analysis of variance (ANOVA). Because all observed parameters analyzed by 2-way ANOVA had significant $(P<$ 0.05 ) year or year by treatment interaction, all variables were analyzed by year. Variables were regressed against shade with least square regression. Parameter means plus or minus standard error by treatment and year are given. For the disease data, ordinal logistic regression was performed and parameter median by treatment and year reported.

\section{Results and Discussion}

Berry yield. Yield was significantly impacted by shade and year (Fig. 1). In all years, yield decreased with shading, but when $83 \%$ shade was removed from the model, yield losses were insignificant. With $83 \%$ shade, yield losses, compared with full sun, ranged from $33 \%$ in 2016 to $63 \%$ in 2018 . Comparatively, yield loss under $65 \%$ shade ranged between $10 \%$ and $17 \%$ compared with the control. The low yield in the $83 \%$ treatment could be caused by the increase in disease pressure and by limited carbon capture under reduced solar irradiance. The maintenance of yield under $37 \%$ to $65 \%$ shade may be due to utilization of existing stored carbon to preferentially allocate biomass toward reproduction immediately following shade treatment initiation and into the following years (Fernandez and Pritts, 1996). Yield was lower in 2016 than 2018, and 2017 had the highest yield. Climatic conditions also have a significant effect on black currant yields, which may account for the significant seasonal variation in yield (Heide and Sønsteby, 2012; Kahu et al., 2009; Opstad et al., 2007). These results reinforce the view that currants can be a valuable contributor to the productivity of woody polycultures by maintaining yields under moderate shade.

Our results are consistent with the modest yield losses found by Toldam-Andersen and Hansen (1993), who reported an 8\% reduction in yield for black currants grown under $50 \%$ shade. When observing shade effects on the yield of five black currant cultivars, Djordjevic et al. (2014) found mixed results across seasons and cultivars. In the first year, no yield loss was observed across cultivars, whereas in the second year, three of the five cultivars had yield losses at either $30 \%$ or $50 \%$ shading, whereas one cultivar had yield loss across both shade treatments. In a similar study on blueberries, Kim et al. (2011) found that blueberries performed well in up to $60 \%$ shading, whereas heavier shading reduced yield significantly. In larger shrubs, Hampson et al. (1996) observed greater yield loss from shade in two cultivars of hazelnuts, with losses of $45 \%$ in $30 \%$ shade and $82 \%$ reduction in $92 \%$ shade. Overall, our research indicates that black currants in the Midwest can maintain acceptable yields at up to $65 \%$ shade, but yields will be 


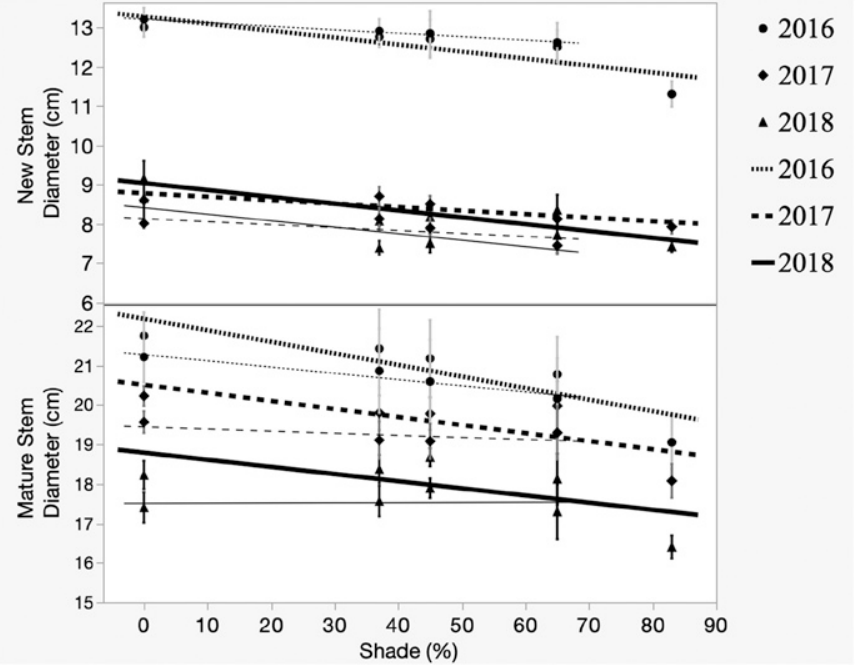

Fig. 5. Artificial shade effect on new (top) and mature (bottom) stem diameter of 'Consort' black currant grown in Urbana, IL. Values are given as diameter in $\mathrm{cm}$ plus or minus standard error. Thicker lines represent fit line with all treatments, whereas thinner lines represent fit line with the $83 \%$ shade treatment removed. Regression equations (where $\mathrm{x}=$ percent shade): New stem diameter $(2016)=$ $13.27-0.0178 \mathrm{x}, r^{2}=0.34, P=0.0074$; New stem diameter(2017) $=8.77-0.0089 \mathrm{x}, r^{2}=0.32, P=$ 0.0094; New stem diameter(2018) $=9.04-0.0174 \mathrm{x}, r^{2}=0.42, P=0.0020 ;$ Mature stem diameter(2016) $=22.18-0.0293 \mathrm{x}, r^{2}=0.22, P=0.0375$; Mature stem diameter(2017) $=20.51-$ $0.0204 \mathrm{x}, r^{2}=0.28, P=0.0175$; Mature stem diameter(2018) $=18.79-0.0183 \mathrm{x}, r^{2}=0.23, P=0.0325$. Regression without $83 \%$ shade was not significant for new stem diameter with $P=0.3142, P=0.1446$, and $P=0.0672$ for 2016, 2017, and 2018, respectively, and for mature stem diameter with $P=0.4195$, $P=0.5950$, and $P=0.9622$, for 2016, 2017, and 2018, respectively.

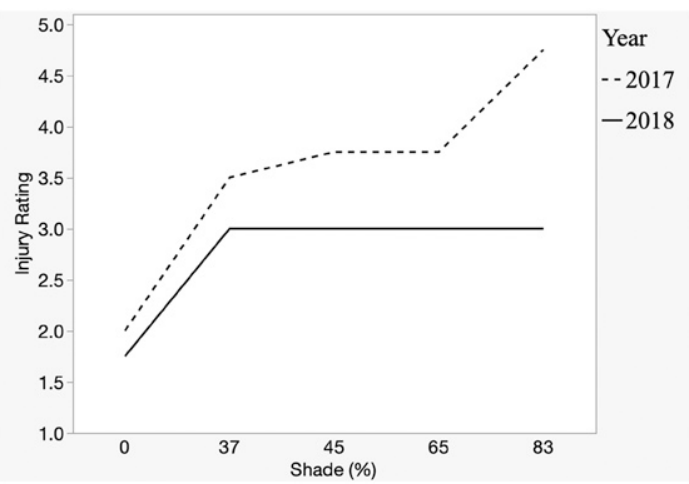

Fig. 6. Artificial shade effects on powdery mildew injury of 'Consort' black currant grown in Urbana, IL. Plant injury was recorded on 23 June 2017 and on 25 June 2018. Values are given as the median of visual ratings of damage. Visual ratings were as follows: $0=$ no powdery mildew; $1=$ powdery mildew detected; $2=6$ to 20 leaves damaged, presence of powdery mildew mycelium; $3=20+$ leaves damaged or infected; 4 = deep leaf browning; 5 = full tissue necrosis on leaves and powdery mildew on shoot tips; $6=$ necrosis of old shoots and leaves; $7=$ plant dieback and/or infected fruit; $8=+50 \%$ plant tissue necrosis; $9=$ plant death. Injury (2017) $P=<0.0001, r^{2}=0.23$; Injury(2018) $P=0.0009, r^{2}=0.39$.

significantly reduced at shade levels greater than $65 \%$.

Harvest phenology. A clear and consistent ripening process is invaluable for producers to determine harvest timing. Berry ripening started on 7 June 2016, 26 May 2017, and 13 June 2018. Berry harvest began on 5 July 2016, 23 June 2017, and 6 July 2018. The results from our study showed that after the first year in 2016, the plants were able to adapt to the shaded environment and maintain a uniform berry ripening timeline (Fig. 2). Although the variation in ripening was less skewed in 2017, there was still a delay in ripening across treatments, which led to the control and $37 \%$ treatment reaching harvest time $5 \mathrm{~d}$ before the $45 \%, 65 \%$, and $83 \%$ treatments. By 2018 , the ripening timeline was similar across all treatments. Our results were less extreme than Djordjevic et al. (2014), who found that light green shade netting with an estimated $30 \%$ shading delayed ripening by up to a week.

Leaf morphology. Changes in leaf morphology can serve as indicators for positive plant responses to shading and long-term impacts on plant growth. Leaf plasticity corresponded to expectations for shade- tolerant species as outlined by Boardman (1977) and Valladares and Niinemets (2008). SLW decreased and leaf area increased with shade (Fig. 3). Yearly variations in SLW were seen, with 2018 having higher SLW than in 2016 and 2017. SLW decreased $26 \%$ to $41 \%$ in $83 \%$ shade when compared with full sun. Leaf area was not significantly different by year, but there was a significant year by treatment interaction. Leaf area increased with shading in 2016 and 2018, with no change in 2017. Leaf area increased under $83 \%$ shade by $24 \%$ in 2016 and by $51 \%$ in 2018.

Our research confirmed results by Toldam-Andersen and Hansen (1993) who observed a decrease in leaf thickness and an increase in leaf area in black currants. Similarly, in olives, Gregoriou et al. (2007) found a significant increase in leaf area as the level of shading increased. In contrast, Heuvel et al. (2004) found leaf area was unaffected by shade in grapes, but an effect on leaf density and weight was observed, similar to 1 year of our study in which there was no effect on leaf area but SLW decreased.

Stem morphology. Limited height plasticity under shade conditions was the greatest indicator of a shade species adaptation found by Valladares and Niinemets (2008). Our results confirmed the understanding that black currants are a shade-adapted species, with limited height plasticity and reduced apical dominance. Height increased in all 3 years, but was limited to only a $6 \%$ to $9 \%$ increase from open sun to $83 \%$ shade (Fig. 4). The results of our study confirmed those of Toldam-Andersen and Hansen (1993) and Djordjevic et al. (2014), who similarly observed limited height plasticity in black currants. On blackberries, Gallagher et al. (2015) observed minimal stem elongation in up to $50 \%$ shading, but an increase in height with $80 \%$ shading.

Stem rejuvenation was similar between the control and the shade treatments, an important consideration as producers require healthy rejuvenation of new fruiting stems (Fig. 4). The number of new basal stems varied by year, with the greatest rejuvenation of 18 new basal stems in 2017 and the least in 2016 with 10 stems. Shade had no effect on stem rejuvenation in 2016 and 2017. In 2018, there was a $43 \%$ decrease in the number of new stems, from 14 in full sun to eight in $83 \%$ shade.

Stem diameter decreased with shading in both new stems and mature stems (Fig. 5). However, when $83 \%$ shade was removed from the models, both new and mature stem diameter was unaffected by shading. When $83 \%$ was included in the model, a decrease in new stem diameter of $8 \%$ to $19 \%$ was observed from open sun to $83 \%$ shade. Mature stem diameter decrease was more consistent with a diameter loss of $10 \%$ to $11 \%$ from the open sun to $83 \%$ shade.

Our results were similar to previous research by Toldam-Andersen and Hansen (1993) that found a decrease in stem diameter with shading but no effect on the number of 
stems produced by the plant. Similarly, Gallagher et al. (2015) found no difference in the number of primocanes produced in blackberries grown across varying levels of artificial shade, but they observed a decrease in stem diameter when $50 \%$ and greater shade levels were imposed. Although stem diameter was still large enough to bear fruit, a reduction in stem diameter may be a sign of decreased plant health and a reduction in fruit load during the growing season and may be a concern when plants are grown in shade greater than $65 \%$.

Plant injury. Shade increased powdery mildew severity across all shade treatments, even with regular applications of horticultural oil and horticultural oil plus potassium bicarbonate (Fig. 6). In 2017, the lowest injury was six to 20 leaves damaged in full sun and the greatest injury was leaf and shoot tip necrosis under $83 \%$ shade. In 2018, fullsun only powdery mildew mycelium was observed, whereas $83 \%$ shade had more than 20 leaves injured and the onset of leaf necrosis. The limited severity in 2018 may be accounted for by the introduction of potassium bicarbonate into the fungicide regimen. Plant health is critical to plant survival and productivity. Our results indicated that for shaded systems, the injury to plants from disease is a major issue due to the increased risk of leaf injury with lower leaf density (Gommers et al., 2013) and the increased humidity and lower light irradiance optimizing the growing conditions of diseases like powdery mildew (Valladares et al., 2016). Even when fungicides are used, severe plant injury can occur from disease when plants are grown under shade.

The effect of disease on crop yield also may explain the decrease in berry yield with greater than $65 \%$ shade. Kater et al. (1992) found reduced yields in annuals grown in understory conditions due to an increase in fungal diseases. Indeed, our study showed the highest fungal damage in the $83 \%$ shade treatment. In addition, mildews have been shown to reduce shade tolerance in temperate forest species (Valladares and Niinemets, 2008) and can in addition decrease the level of irradiance that makes it to plant leaves due to obstruction and leaf tissue damage (Valladares et al., 2016). With many new cultivars with increased disease resistance available to producers, the yield loss due to increased disease presence in shaded environments may be reduced. Our results show the importance of selecting for disease resistance in understory crops, as the understory environment increases the overall risk of disease in plants and can be a major contributor to plant injury and subsequent crop yield loss.

Overall, the results of this study indicate that 'Consort' black currant is an excellent understory crop in light to moderate shade conditions. With a phenotypic plasticity common to shade species, 'Consort' black currant was able to maintain a substantial yield under shade stress. Further, black currant germplasm could be screened to determine shade-tolerant and disease-resistant cultivars. These superior cultivars would be useful in a breeding program to further enhance productivity under shade. Black currants may prove beneficial in polyculture, providing fruit and nut orchard growers with an additional crop in the system that could increase yield and income without tapping additional land resources.

\section{Literature Cited}

Bayala, J., J. Sanou, Z. Teklehaimanot, and F. Sinclair. 2015. Adaptation of crops to partial shade in mixed cropping systems, p. 309-325. In: C.K. Ong, C. Black, and J. Wilson (eds). Tree-crop interactions: agroforestry in a changing climate. 2nd ed. CAB Intl., Wallingford, UK.

Boardman, N.K. 1977. Comparative photosynthesis of sun and shade plants. Annu. Rev. Plant Physiol. 28(1):355-377.

Bote, A.D. and P.C. Struik. 2011. Effects of shade on growth, production and quality of coffee (Coffea arabica) in Ethiopia. J. Hort. For. 3(11):336-341.

Djordjevic, B., K. Šavikin, D. Djurovic, R. Veberic, M. Mikulič-Petkovšek, G. Zdunić, and T. Vulic. 2014. Biological and nutritional properties of blackcurrant berries (Ribes nigrum L.) under conditions of shading nets. J. Sci. Food Agr. 95(12):2416-2423.

Fernandez, G.E. and M.P. Pritts. 1996. Carbon supply reduction has a minimal influence on current year's red raspberry (Rubus idaeus L.) fruit production. J. Amer. Soc. Hort. Sci. 121(3):473-477.

Gallagher, E.J., K.W. Mudge, M.P. Pritts, and S.D. DeGloria. 2015. Growth and development of 'Illini Hardy' blackberry (Rubus subgenus Eubatus Focke) under shaded systems. Agrofor. Syst. 89(1):1-17.

Geils, B.W., K.E. Hummer, and R.S. Hunt. 2010. White pines, Ribes, and blister rust: A review and synthesis. For. Pathol. 40(3-4):147-185.

Gommers, C.M.M., E.J.W. Visser, K.R.S. Onge, L.A.C.J. Voesenek, and R. Pierik. 2013. Shade tolerance: When growing tall is not an option. Trends Plant Sci. 18(2):65-71.

Gopalan, A., S.C. Reuben, S. Ahmed, A.S. Darvesh, J. Hohmann, and A. Bishayee. 2012. The health benefits of blackcurrants. Food Funct. 3(8):795-809.

Greer, D.H., C. Weston, and M. Weedon. 2010. Shoot architecture, growth and development dynamics of Vitis vinifera cv. Semillon vines grown in an irrigated vineyard with and without shade covering. Funct. Plant Biol. 37(11):10611070.

Gregoriou, K., K. Pontikis, and S. Vemmos. 2007. Effects of reduced irradiance on leaf morphology, photosynthetic capacity, and fruit yield in olive (Olea europaea L.). Photosynthetica 45(2):172-181.

Hampson, C.R., A.N. Azarenko, and J.R. Potter. 1996. Photosynthetic rate, flowering, and yield component alteration in hazelnut in response to different light environments. J. Amer. Soc. Hort. Sci. 121(6):1103-1111.

Heide, O.M. and A. Sønsteby. 2012. Floral initiation in black currant cultivars (Ribes nigrum
L.): Effects of plant size, photoperiod, temperature, and duration of short day exposure. Scientia Hort. 138:64-72.

Heuvel, J.E.V., T.A. Proctor, K.H. Fisher, and J.A. Sullivan. 2004. Shading affects morphology, dry-matter partitioning, and photosynthetic response of greenhouse-grown 'Chardonnay' grapevines. HortScience 39:65-70.

Hummer, K.E. and D.L. Barney. 2002. Crop reports. Currants. HortTechnology 12(3):377388.

Hummer, K.E. and A. Dale. 2010. Horticulture of Ribes. For. Pathol. 40(3/4):251-263.

Hunter, A.W.S. 1955. Black currants, p. 26-29. Prog. Rep. Central Experimental Farm, Ottawaa, ON

Kahu, K., H. Janes, A. Luik, and L. Klaas. 2009. Yield and fruit quality of organically cultivated blackcurrant cultivars. Acta Agr. Scand. B Soil Plant Sci. 59(1):63-69.

Kater, L.J.M., S. Kante, and A. Budelman. 1992. Karité (Vitellaria paradoxa) and néré (Parkia biglobosa) associated with crops in South Mali. Agrofor. Syst. 18(2):89-105.

Kim, S.J., D.J. Yu, T.-C. Kim, and H.J. Lee. 2011. Growth and photosynthetic characteristics of blueberry (Vaccinium corymbosum cv. Bluecrop) under various shade levels. Scientia Hort. 129(3):486-492.

Lovell, S.T., C. Dupraz, M. Gold, S. Jose, R. Revord, E. Stanek, and K.J. Wolz. 2017. Temperate agroforestry research: Considering multifunctional woody polycultures and the design of long-term field trials. Agrofor. Syst. 92:1397-1415.

Malézieux, E., Y. Crozat, C. Dupraz, M. Laurans, D. Makowski, H. Ozier-Lafontaine, B. Rapidel, S. Tourdonnet, and M. Valantin-Morison. 2009. Mixing plant species in cropping systems: Concepts, tools and models. A review. Agron. Sustain. Dev. 29(1):43-62.

Opstad, N., A. Nes, F. Måge, and B. Hageberg. 2007. Effects of fertilization and climatic factors in a long-term experiment with blackcurrant (Ribes nigrum L.) cv. Ben Tron. Acta Agr. Scand. B Soil Plant Sci. 57(4):313-321.

Rivera, T.M., M.F. Quigley, and J.C. Scheerens. 2004. Performance of component species in three apple-berry polyculture systems. HortScience 39:1601-1606.

Šavikin, K., M. Mikulič-Petkovšek, B. Djordjević, G. Zdunić, T. Janković, D. Djurović, and R. Veberič. 2013. Influence of shading net on polyphenol profile and radical scavenging activity in different varieties of black currant berries. Scientia Hort. 160:20-28.

Toldam-Andersen, T.B. and P. Hansen. 1993. Growth and development in black currants (Ribes nigrum). I. Effects of light and leafshoot removals on growth distribution and fruit drop. Acta Hort. 352(34):237-246.

Valladares, F., L. Laanisto, Ü. Niinemets, and M.A. Zavala. 2016. Shedding light on shade: Ecological perspectives of understory plant life. Plant Ecol. Divers. 9(3):237-251.

Valladares, F.L. and Ü. Niinemets. 2008. Shade tolerance, a key plant feature of complex nature and consequences. Annu. Rev. Ecol. Evol. Syst. 39(1):237-257.

Wolz, K.J., S.T. Lovell, B.E. Branham, W.C. Eddy, K. Keeley, R.S. Revord, M.M. Wander, W.H. Yang, and E.H. DeLucia. 2018. Frontiers in alley cropping: Transformative solutions for temperate agriculture. Glob. Change Biol. 24(3):883-894. 